ついて譲明さる。

12. 視神經管孔心X線像撮影心就いて

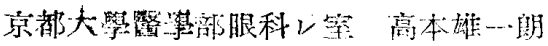

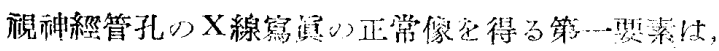

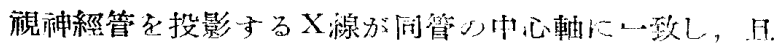

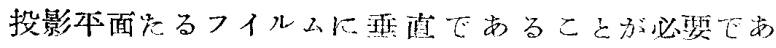

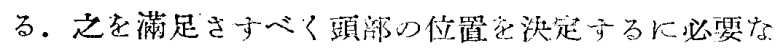

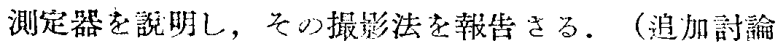
あり)

13. 視神經孔 X線撮影術式

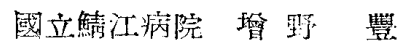

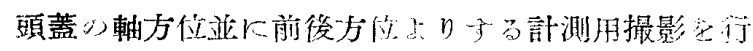

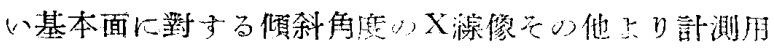

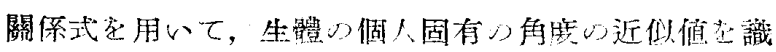

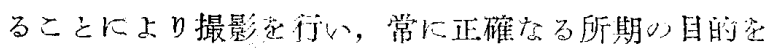
達している。（追加討諭况り）

\section{特別講演 X線障程對策}

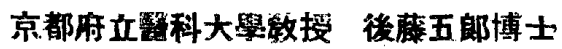

秎80分間に互り，斯界の第一人者である後滕搏士心

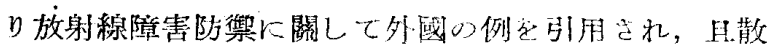

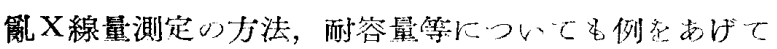

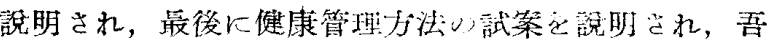
々に深い感銘を與えられ方。

\section{畫 食 休 恶}

14、輕度の斜位に撮影され胸部寫真の考察

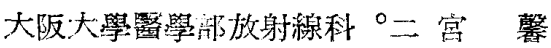

$$
\begin{aligned}
& \text { 片忚洮幸 }
\end{aligned}
$$

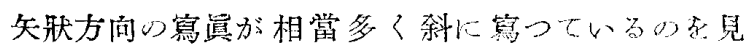

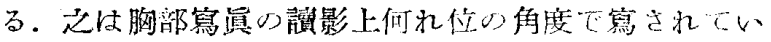

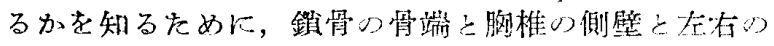
差を比較することにした。

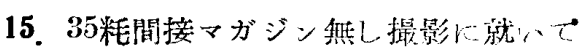

名古屋蓺田保健所内藤正一

16. 第一次胸部撮影に於ける最適管電洎り洪定に關一 る考察大阪府立大阪病院 梅浴支富

一次撮影（假稱）に於いて理論的，並飞粉末キルク

層及び水槽を以て構成なしたる人工肺吸收層り撮影又 透過線量の測定等賽驗的結舁より，肺野に包裹せらる

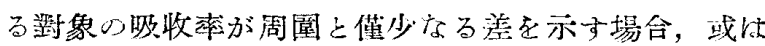

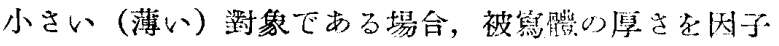

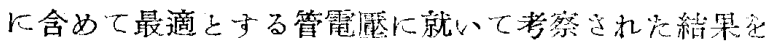
郝告さる。

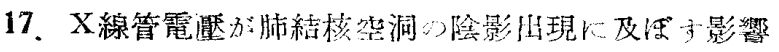
の實驗的科究に就いて

國立久留米病院 ${ }^{\circ}$ 志泉元治
上野哲 郎

寺崎郁子

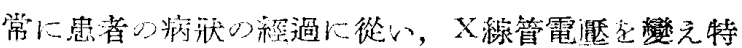

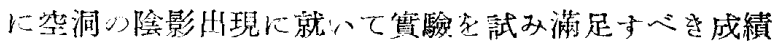

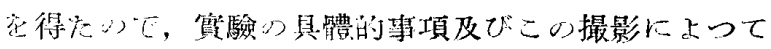
得ら礼てる空洞㓌影の臨䏞症狱との比較等について報 告.

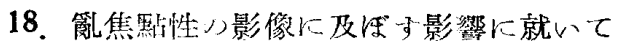

$$
\text { 大日本レントゲン丹狗勇 }
$$

大阪大學醫學激放射線科付田 勝

${ }^{\circ}$ 出中仁

X線管球焦點の亂視現象は禹知心事で方るが，茲に

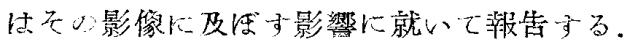

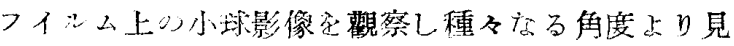

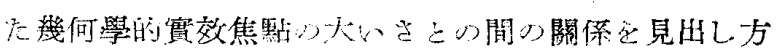

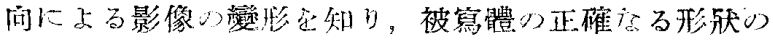

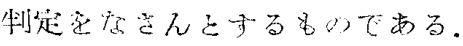

19.屋體血管撮影心浩影劑について

\section{日本赫十字社酷院 金澤 章}

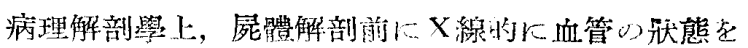

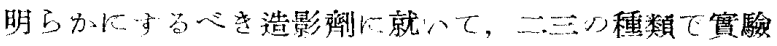

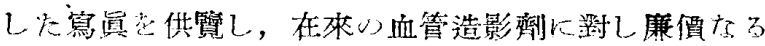
硫酸バリウムの應用が，新處法にてほぼ日的圭澾し得 百事孝報告.

29. 各種造影劑使用時に於け召撮影條件に就いて 大阪大學慧學部放射線科 星野卓三

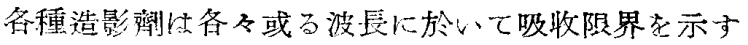

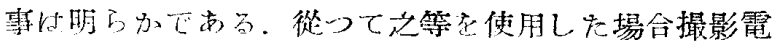

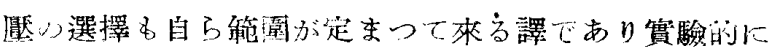
地等安求め字のである。

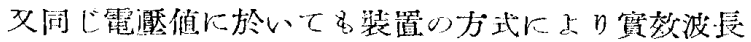

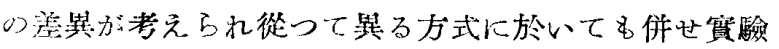
を们つた結果主報告,

21. 籣易心搏連動笠置について

伊豆㜊管病院 ○渡邊明道 清水克䇺

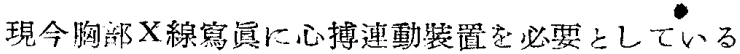

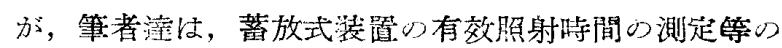

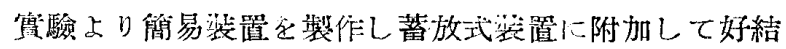

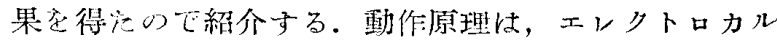
ジォグラフに依り火棘つ光圭峝轉する接觸子下虽て，

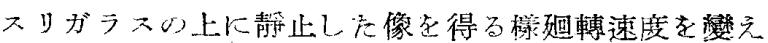
刷子亡南結してスリガラスの表示點然投影上合致させ

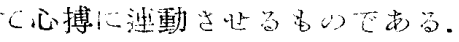

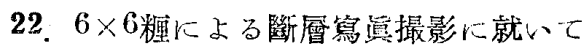

